\title{
Kendali Kaki Robot oleh Ketegangan Otot Berbasis Elektromiografi dan Mikrokontroler ATmega8535
}

\author{
Vincent Nanda Rudy Gondoatmojo1) , Florentinus Budi Setiawan²) \\ 1,2Program Studi Teknik Elektro, Fakultas Teknik, Universitas Katolik Soegijapranata \\ Semarang, Indonesia \\ vincentnrg38@gmail.com, fbudisetiawan@yahoo.com
}

\begin{abstract}
Abstrak
Saat ini teknologi sudah sangat maju dan berkembang dengan pesat. Perkembangan ini dapat kita jumpai pada bidang elektro medis dan mekanika. Sudah banyak sekali robot - robot yang menggantikan peran manusia di bidang industri, begitu juga banyak sekali robot yang dibuat untuk menggantikan peran anggota tubuh manusia yang tidak berfungsi. Salah satu yang sedang berkembang saat ini adalah robot kaki untuk mengganti peran kaki penyandang disabilitas yang hanya memiliki satu kaki untuk menggantikan peran bagian kaki lainnya. Robot ini bekerja dengan menggunakan rangkaian elektromiografi dan mikrokontroler memanfaatkan sinyal otot pada bagian kaki yang masih berfungsi untuk dibaca dan diolah sebagai referensi untuk menggerakkan kaki robot. Pergerakan kaki robot dimotori oleh motor servo yang seolah bekerja sebagai sendi dan pergerakan motor servo diatur oleh sinyal PWM yang dihasilkan oleh mikrokontroler dengan mengolah sinyal keluaran dari rangkaian Elektromiografi yang didapat setelah membaca sinyal otot kaki yang masih berfungsi ketika kontraksi dan relaksasi. Pada makalah ini dilakukan pengujian dengan mendeteksi sinyal otot kaki untuk menggerakkan robot kaki agar dapat mengikuti pergerakan kaki sebagai referensi. Pada hasil pengujian menunjukkan bahwa robot kaki dapat mengikuti dengan tepat pergerakan kaki yang digunakan sebagai referensi.
\end{abstract}

Kata Kunci : Sinyal otot, elektromiografi, PWM, motor servo, kaki robot.

\section{Pendahuluan}

Dilihat dari masa ke masa, perkembangan teknologi sudah sangat maju, beberapa diantaranya adalah bidang mekanika dan elektro medis. Kedua bidang ini memiliki peranan yang penting dalam kehidupan manusia terutama untuk penyandang disabilitas. Para penyandang disabilitas memiliki banyak permasalahan dalam kehidupan sehari-hari, hal ini menyebabkan mereka mengalami kesulitan untuk memenuhi kegiatan harian mereka[1].

Pada bidang mekanika, robot dapat digunakan untuk mengganti fungsi kerja dari bagian tubuh yang tidak berfungsi pada penyandang disabilitas. Untuk menunjang hal tersebut, dibutuhkan pendeteksian sinyal otot pada bagian lain sebagai referensi untuk menggerakkan robot. Cara yang paling mudah untuk mendeteksi sinyal otot adalah dengan menggunakan sensor elektromiografi. Dikarenakan sinyal otot terlalu sensitif dan mudah sekali terkontaminasi dengan sinyal gangguan, maka dibutuhkan proses filtering dan penguatan[2][3].

Pada pembahasan kali ini, lebih difokuskan pada pendeteksian sinyal otot kaki. Ada 3 titik otot kaki yang digunakan sebagai referensi, yaitu rectus femoris, biceps femoris, dan gastrocnemius. Cara kerja dari alat ini, ketiga titik otot referensi dideteksi dengan elektroda, kemudian dikuatkan dengan rangkaian EMG serta dikuatkan lagi dengan penguatan inverting, kemudian disearahkan dan di filter dengan rangkaian envelope detector lalu diproses menggunakan mikrokontroler untuk menampilkan tingkat ketegangan otot pada tampilan LCD dan untuk menggerakkan tiga servo motor, dapat dilihat pada gambar 1. Gambaran umum alat ini yaitu ketika kaki digerakkan, robot kaki akan mengikuti gerakan kaki berdasarkan perubahan sinyal ketegangan otot pada kaki.

\section{Dasar Teori}

Untuk pembuatan alat, digunakan beberapa komponen penting sebagai penunjang agar alat dapat beroperasi dengan baik dan mendapatkan hasil yang diinginkan. Berikut ini merupakan penjelasan komponen - komponen penting dalam pembuatan alat.

\subsection{Elektroda}

Elektroda berfungsi untuk membaca dan menghantarkan sinyal otot dari permukaan kulit ke rangkaian EMG[4]. Elektroda yang digunakan adalah elektroda gel. Gel ini berfungsi untuk mengurangi noise/gangguan yang diakibatkan dari kerenggangan udara di antara permukaan kulit dan elektroda. Dengan adanya gel, kerenggangan udara bisa diminimalisir karena terisi gel. 


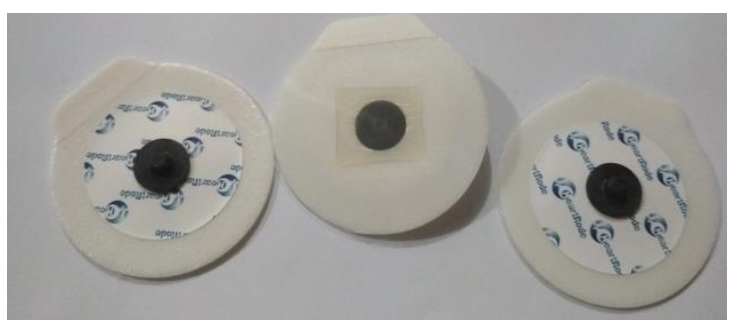

Gambar 1. Elektroda Perak Klorida dengan gel

Gel ini berguna untuk memaksimalkan pembacaan sinyal otot dikarenakan permukaan kulit pada manusia tidak rata dan terdapat pori - pori, gel ini berfungsi untuk mengisi kekosongan pada bagian yang tidak rata agar meminimalisir gangguan pada pembacaan. Elektroda yang digunakan sebanyak 3 buah, elektroda 1 diletakkan pada bagian tengah/puncak otot, elektroda 2 diletakkan pada bagian akhir otot, dan elektroda 3 diletakkan pada bagian kulit yang tidak terdapat otot.

\section{$2.2 \quad I C A D 620$}

IC AD620 berfungsi untuk menguatkan sinyal otot yang dibaca oleh elektroda dalam bentuk MUAP(Motor Unit Action Potential). Penguat ini digunakan karena sinyal otot yang terbaca oleh elektroda sangatlah kecil, sehingga dibutuhkan penguat agar sinyal dapat diproses dengan lebih mudah[5].

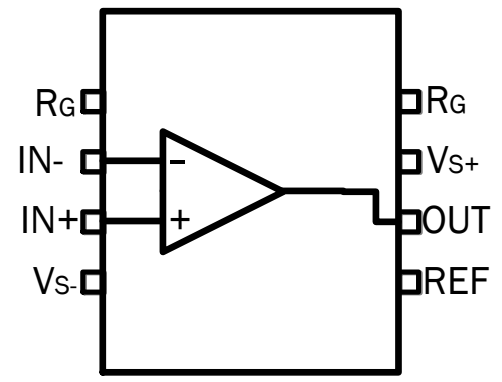

Gambar 2. Diagram AD620

\section{$2.3 \quad O p-A m p$}

Op-amp merupakan sebuah komponen yang memilik banyak fungsi operasi, dan seringnya OPAMP digunakan sebagai penguat[5]. Berikut ini merupakan gambar diagram dari Op-amp.

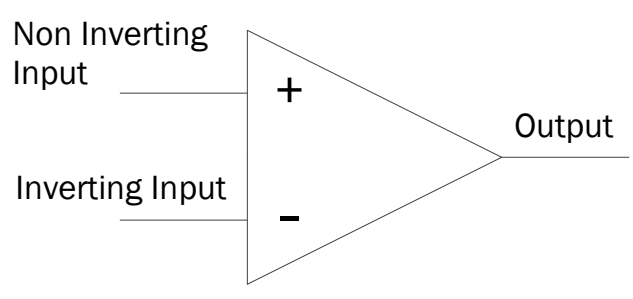

Gambar 3. Diagram Op-amp

\subsection{Envelope detector}

Envelope detector berfungsi untuk mengikuti dan mempertahankan tiap tiap nilai puncak yang dihasilkan pada penguatan sebelumnya[6]. Envelope detector terdiri dari rangkaian diode sebagai penyearah setengah gelombang dan rangkaian low pass filter sebagai filter.

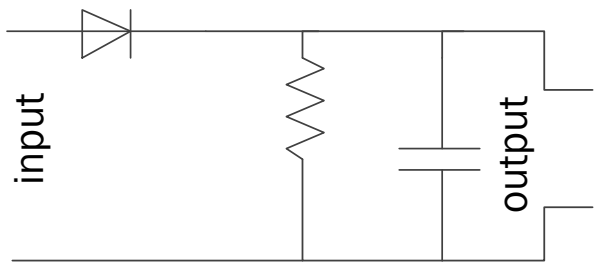

\section{Gambar 4. Rangkaian Envelope Detector}

\section{Perancangan Alat}

Alat ini bekerja dengan memanfaatkan sinyal otot yang dibaca oleh elektroda, yang kemudian sinyal otot yang terbaca oleh elektroda diteruskan ke rangkaian EMG untuk diolah dengan dikuatkan sebanyak 500 kali agar sinyal otot dapat terlihat dengan jelas dan kemudian dikuatkan kembali sebanyak 2 kali oleh rangkaian penguat inverting, sehingga total penguatan dari alat ini adalah 1000 kali. Kemudian sinyal keluaran dari penguat inverting distabilkan oleh buffer dan diteruskan ke rangkaian envelope detector untuk mempertahankan nilai tiap puncak sinyal otot yang telah dikuatkan, dan untuk merubah sinyal otot yang masih berupa impuls menjadi tegangan DC agar dapat dibaca oleh mikrokontrol sebagai ADC dan kemudian diolah menggunakan program untuk dapat menampilkan data nilai tegangan otot ketika rileks dan kontraksi pada LCD dan untuk menghasilkan sinyal PWM (Pulse Width Modulation) untuk dapat memutar motor servo agar kaki robot dapat bergerak.

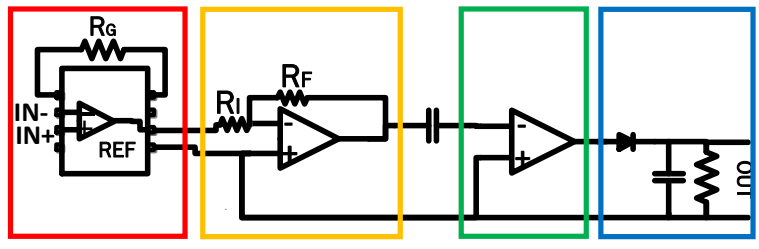

Gambar 5. Rangkaian Elektromiografi, Penguat Inverting, Buffer, Envelope Detector

\subsection{Rangkaian Elektromiografi}

Pada gambar 5, rangkaian elektromiografi ditunjukkan oleh kotak merah. Rangkaian elektromiografi menggunakan AD620 sebagai IC. AD620 berfungsi untuk menguatkan sinyal otot 
yang dibaca oleh elektroda. Nilai penguatan pada AD620 bisa bervariasi berdasarkan nilai RG yang terhubung pada kaki 1 dan 8 dengan persamaan :

$$
G=1+(49.4 K \Omega / R G)[7]
$$

Pada alat ini digunakan nilai $\mathrm{Rg}$ sebesar $100 \Omega$, sehingga didapatkan nilai penguatan 495 kali atau bisa disebut \pm 500 kali. Sedangkan untuk memproses sinyal otot yang dibaca oleh elektroda, elektroda 1 dikoneksikan ke kaki 2 sebagai $\mathrm{Vin}_{\text {+, }}$ elektroda 2 dikoneksikan ke kaki 3 sebagai Vin-, dan elektroda 3 dikoneksikan ke Kaki 5 sebagai Tegangan referensi[8]. Tengangan keluaran dari AD620 terdapat pada kaki 7 dan memiliki nilai tegangan dengan persamaan :

$$
V_{\text {out }}=\left(V_{\text {in }}+-V_{\text {in- }}\right) * G-V_{r e f}[9]
$$

\subsection{Penguat Inverting}

Pada gambar 5, penguat inverting ditunjukkan oleh kotak kuning. Penguat inverting ini menggunakan op-amp yang dirangkai seperti gambar 6 dengan nilai penguatan yang didapatkan dari persamaan :

$$
G=-R f / R i[10]
$$

Dengan $\mathrm{Rf}_{\mathrm{f}}=1000 \Omega$ dan $\mathrm{Ri}_{\mathrm{i}}=500 \Omega$ maka didapatkan penguatan $(G)=-2$ Kali.

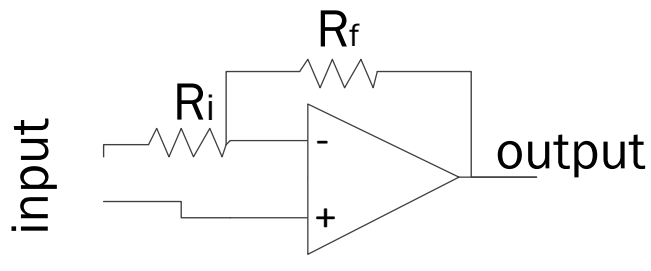

Gambar 6. Rangkaian Penguat Inverting

Nilai keluaran dari rangkaian penguat inverting didapatkan dengan persamaan :

$$
\text { Vout }=-R_{f} / R_{i} \operatorname{Vin}[11]
$$
TL062CP.

Komponen op-amp yang digunakan adalah

\subsection{Buffer}

Pada gambar 5, buffer ditunjukkan oleh kotak hijau. Berfungsi untuk menyetabilkan sinyal keluaran dari penguat inverting. Komponen buffer juga berupa op-amp yang dirangkai seperti pada gambar 5 kotak hijau. Komponen yang digunakan adalah TL062CP.

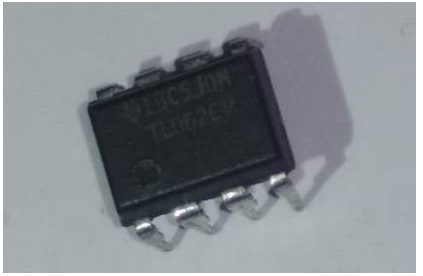

Gambar 7. Bentuk Fisik TL062CP sebagai Buffer

\subsection{Envelope Detector}

Pada gambar 5, rangkaian envelope detector ditunjukkan oleh kotak biru. Berfungsi untuk mengambil tiap nilai puncak keluaran dari penguatan sebelumnya.

\subsection{Mikrokontroler}

Mikrokontroler adalah suatu chip berupa IC (Integrated Circuit) yang dapat menerima sinyal masukan, mengolahnya dan memberikan sinyal keluaran sesuai dengan program yang diisikan ke dalamnya. Sinyal input mikrokontroler berasal dari sensor yang merupakan informasi dari lingkungan sedangkan sinyal keluaran ditujukan kepada aktuator yang dapat memberikan efek ke lingkungan. Jadi secara sederhana mikrokontroler dapat diibaratkan sebagai otak dari suatu perangkat/produk yang mempu berinteraksi dengan lingkungan sekitarnya[3].

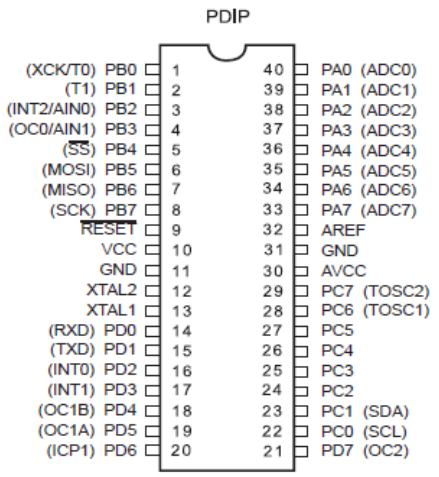

Gambar 8. ATmega8535

Mikrokontrol yang digunakan adalah ATMEGA8535 dengan input yang berasal dari sinyal otot yang telah dikuatkan, disearahkan dan difilter yang kemudian diteruskan ke mikrokontrol sebagai ADC. Kemudian sinyal tersebut diproses oleh mikrokontrol dengan program untuk ditampilkan di LCD dan untuk menggerakkan motor servo. 


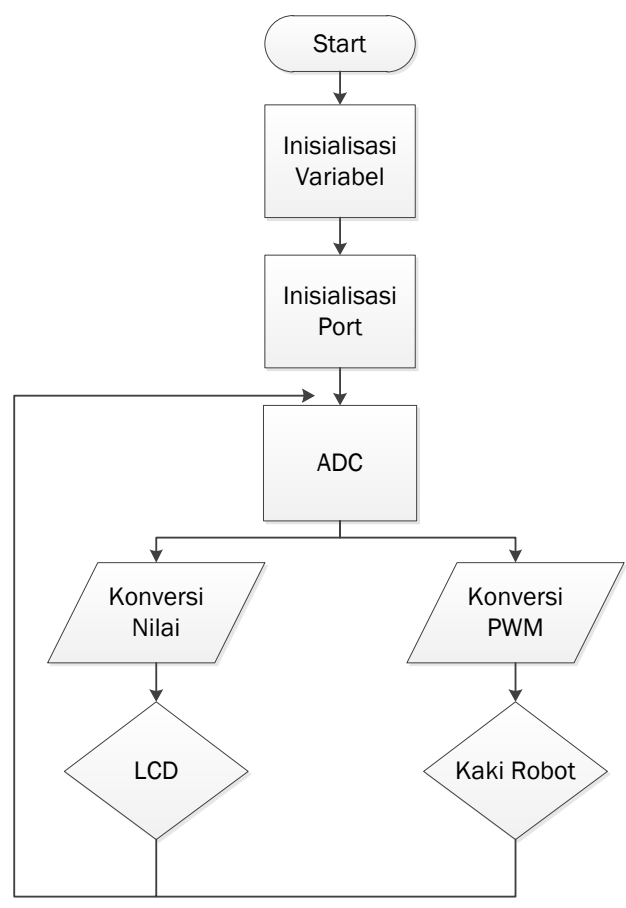

Gambar 9. Diagram Alur Program

\subsection{Motor Servo}

Motor Servo ini berfungsi sebagai halnya sendi pada kaki robot. Motor servo ini dapat berputar dari sudut $-90^{\circ}$ hingga $90^{\circ}$. Cara kerja motor servo adalah dengan memberikan sinyal PWM pada data motor servo[12]. Sinyal PWM didapatkan dengan mengatur program pada mikrokontrol, dan sinyal PWM (Pulse Width Modulation) ini disesuaikan dengan input masukan sinyal otot agar motor DC dapat bergerak sesuai dengan tingkat ketegangan sinyal otot.

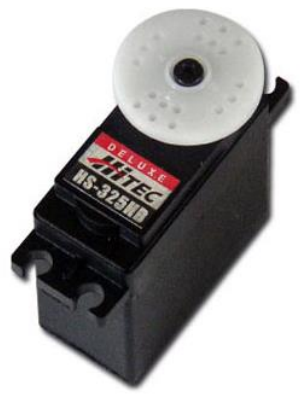

Gambar 10. Motor Servo

\section{Hasil Pengujian}

Pada pengujian ini, komponen yang digunakan adalah elektroda sebagai pembaca sinyal otot, rangkaian EMG sebagai penguat sinyal otot, rangkaian penguat inverting sebagai penguat sinyal otot, buffer sebagai penyetabil sinyal, rangkaian envelope detector sebagai penyearah dan penyaring sinyal agar dapat dibaca oleh mikrokontroler sebagai ADC untuk menggerakkan kaki servo dan untuk menampilkan pada LCD.

Pengujian dilakukan pada tiga titik otot yaitu otot rectus femoris yang terletak pada paha bagian atas, otot biceps femoris yang terletak pada paha bagian bawah, dan otot gastrocnemius yang terletak pada bagian betis.

\section{a. Hasil Pengujian Otot Rectus Femoris}

Pada pengujian otot rectus femoris ketika sedang rileks, didapatkan tegangan keluaran rata - rata sebesar 1 - 1,2 volt DC. Pada fase ini, kaki robot bagian paha berada dalam posisi berdiri tegak, dan posisi servo pertama berada pada posisi $-90^{\circ}$. Ditunjukkan oleh gambar 10 .

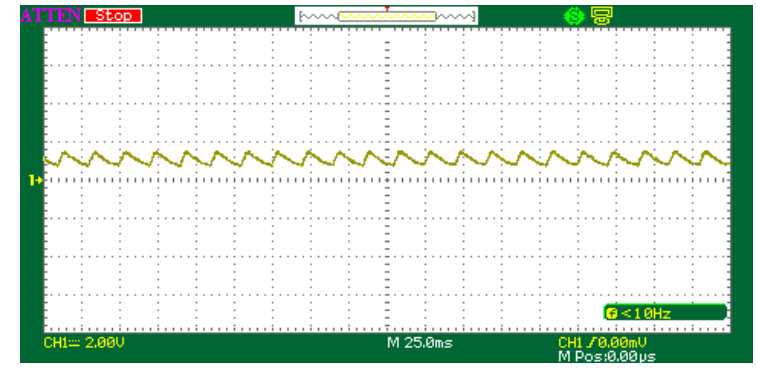

Gambar 11. Hasil Keluaran Tegangan Sinyal Otot Rectus Femoris ketika Rileks

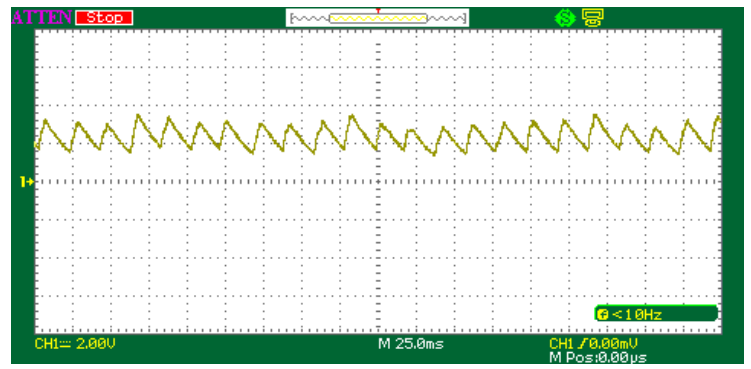

Gambar 12. Hasil Keluaran Tegangan Sinyal Otot Rectus Femoris ketika Tegang

Pada gambar 11 dan 12 menunjukkan hasil pengujian otot rectus femoris ketika sedang kontraksi, didapatkan tegangan keluaran rata rata sebesar 3 - 3,4 volt DC. Pada fase ini, kaki robot bagian paha berada dalam posisi mengangkat, dan posisi servo pertama pada posisi $0^{\circ}$. 


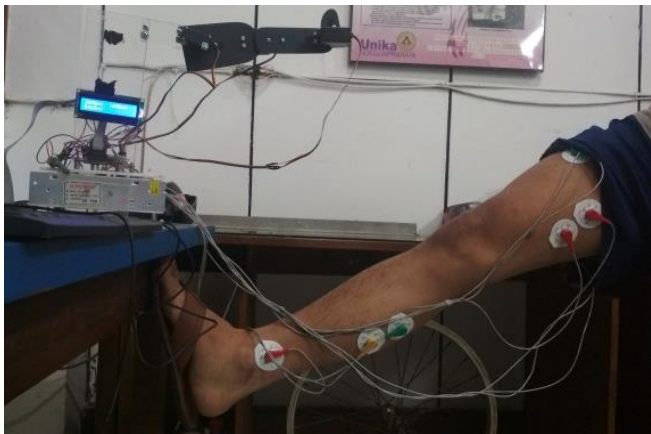

Gambar 13. Hasil Gerakan Kaki Servo ketika Otot Rectus Femoris Kontraksi

\section{b. Hasil Pengujian Otot Biceps Femoris}

Pada pengujian otot biceps femoris ketika sedang rileks, didapatkan tegangan keluaran rata - rata sebesar 0.9 - 1.1 volt DC. Pada fase ini, kaki robot bagian betis berada dalam posisi berdiri tegak, dan posisi servo kedua berada pada posisi $0^{\circ}$. Ditunjukkan oleh gambar 13.

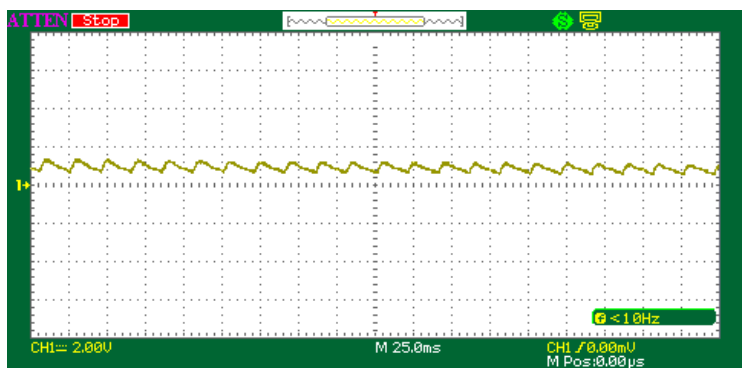

Gambar 14. Hasil Keluaran Tegangan Sinyal Otot Biceps Femoris ketika Rileks

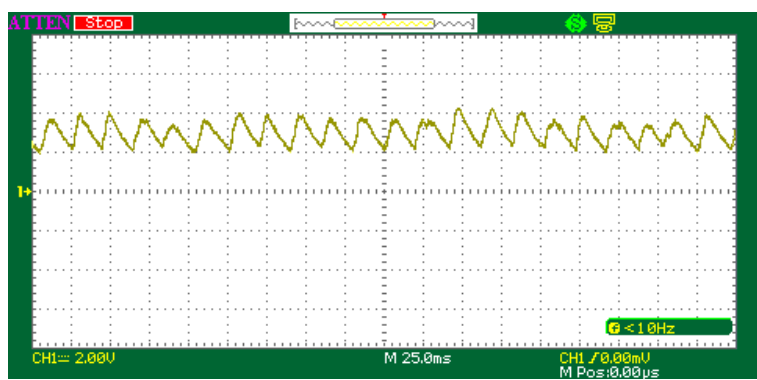

Gambar 15. Hasil Keluaran Tegangan Sinyal Otot Biceps Femoris ketika Kontraksi

Pada gambar 14 dan 15 menunjukkan hasil pengujian otot biceps femoris ketika sedang kontraksi, didapatkan tegangan keluaran rata rata sebesar 3,2 - 3,5 volt DC. Pada fase ini, kaki robot bagian betis berada dalam posisi mengangkat, dan posisi servo kedua berada pada posisi $45^{\circ}$.

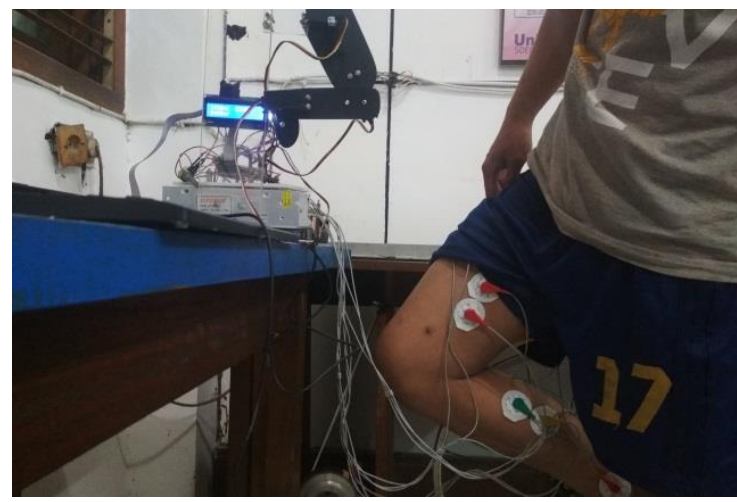

Gambar 16. Hasil Gerakan Kaki Robot ketika Otot Biceps Femoris Kontraksi

\section{c. Hasil Pengujian Otot Gastrocnemius}

Pada pengujian otot gastrocnemius ketika sedang rileks, didapatkan tegangan keluaran rata - rata sebesar 0 - 0.3 volt DC. Pada fase ini, kaki robot bagian telapak berada dalam posisi tegak lurus dengan betis layaknya kaki seseorang yang sedang berdiri tegak, dan posisi servo ketiga pada posisi $0^{\circ}$. Ditunjukkan oleh gambar 16 .

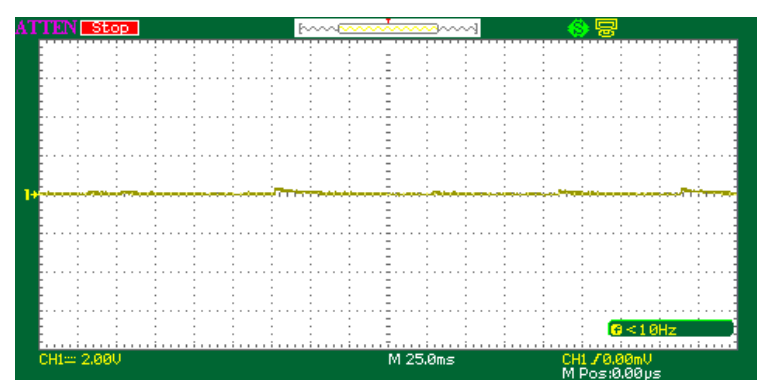

Gambar 17. Hasil Keluaran Tegangan Sinyal Otot Gastrocnemius ketika Rileks

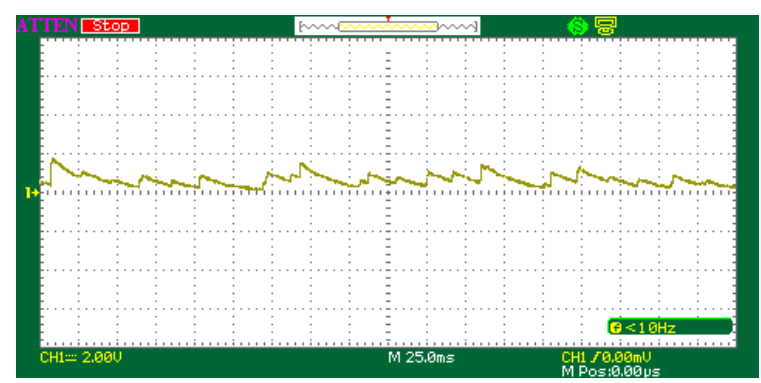

Gambar 18. Hasil Keluaran Tegangan Sinyal Otot Gastrocnemius ketika Kontraksi

Pada gambar 17 dan 18 menunjukkan hasil pengujian otot gastrocnemius ketika sedang tegang, didapatkan tegangan keluaran rata - rata sebesar 1,7 - 1,9 volt DC. Pada fase ini, kaki robot bagian telapak berada dalam posisi mengangkatm dan posisi servo ketiga pada posisi sekitar $75^{\circ}$. 


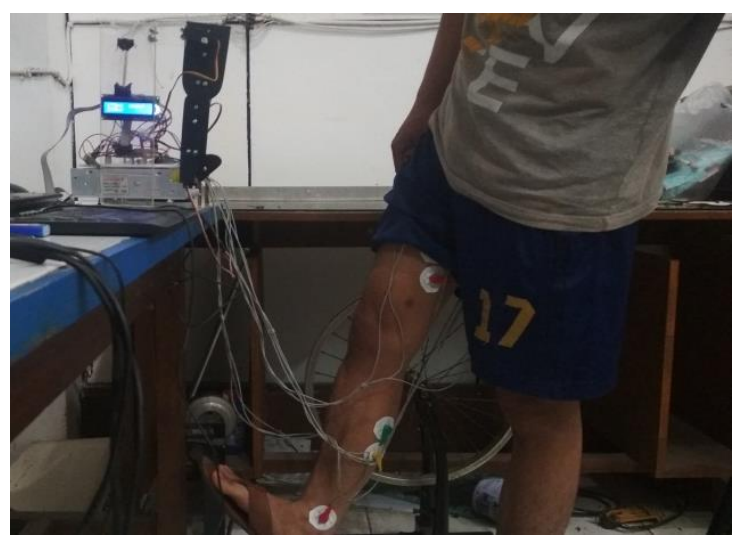

Gambar 19. Hasil Gerakan Kaki Robot ketika Sinyal Otot Gastrocnemius Kontraksi

Gambar 19 menunjukkan gerakan kaki robot ketika semua otot mengalami kontraksi, dan kaki robot bergerak sama dengan gerakan kaki.

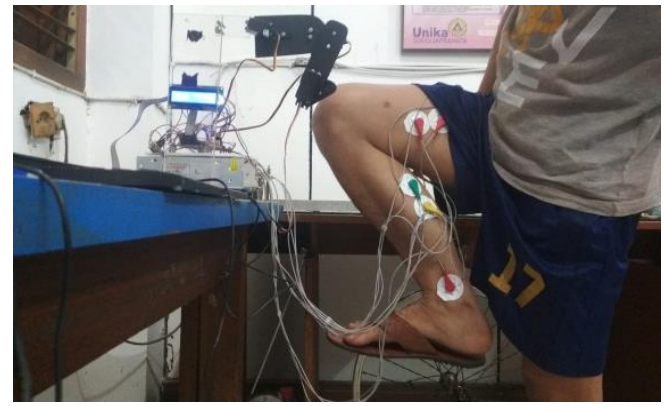

Gambar 20. Hasil Gerakan Kaki Robot ketika Sinyal Otot Rectus Femoris, Biceps Femoris dan Gastrocnemius Kontraksi

Tabel Hasil Pengukuran Sinyal Otot

\begin{tabular}{|c|c|c|}
\hline No & Nama Otot & Hasil \\
\hline 1 & Rectus Femoris & $\pm 3,2$ Volt \\
\hline 2 & Biceps Femoris & $\pm 3,3$ Volt \\
\hline 3 & Gastrocnemius & $\pm 1,8$ Volt \\
\hline
\end{tabular}

\section{Daftar Pustaka}

[1] Syed Faiz Ahmed, Athar Ali, M. Kamran Joyo, M. Rehan, Fahad A. Siddiqui, Jawad A. Bhatti, Aatika Liaquat, "Mobility Assistance Robot for disabled persons using Electromyography(EMG) Sensor", IEEE International Conference on Innovative Research and Development (ICIRD), 2018.

[2] Yeong Jae Kim, Hyun Seon Lee, Seul Jung, "Line Tracking Control of a Mobile Robot Using EMG Signals from Human Hand Gestures", The 12th International Conference on
Ubiquitous Robots and Ambient Intelligence (URAI 2015), 2015.

[3] Florentinus Budi Setiawan, Siswanto, "Multi Channel Electromyography (EMG) Signal”, Proc. of 2016 3rd Int. Conf. on Information Tech., Computer, and Electrical Engineering (ICITACEE), 2016.

[4] Florentinus Budi Setiawan, Siswanto, "Multi Channel Electromyography (EMG) Signal Acqiusition using Microcontroller with Rectifier", Proc. of 2016 3rd Int. Conf. on Information Tech., Computer, and Electrical Engineering (ICITACEE), 2016.

[5] Ricky Fajar Adiputra, Florentinus Budi Setiawan, "ROBOT ARM CONTROLLED BY MUSCLE TENSION BASED ON ELECTROMYOGRAPHY AND PIC18F4550", Proc. Of $20163^{\text {rd }}$ Int. Conf. on Information Tech., Computer, and Electrical Engineering (ICITACEE), 2016.

[6] Florentinus Budi Setiawan, Siswanto, "Electromyography (EM G) Signal Compression using Sinusoidal Segmental Model", Proc. of 2015 2nd Int. Conference on Information Technology, Computer and Electrical Engineering (ICITACEE), 2015.

[7] Analog Devices. 2003. "Low Cost Low Power Instrumentation Amplifier". One Technology Way.

[8] Kevin Eka Pramudita, F.Budi Setiawan, Siswanto, "Interface and display of Electromyography signal wireless measurements", $20141^{\text {st }}$ International Conference on Information Technology, Computer and Electrical Engineering (ICITACEE), 2014.

[9] Wang Yu, Liu Donghui, Hong Wenxue, "A Measurement of Acupoints Bioimpedance based on PCI8335B", International Conference on Computer Application and System Modeling (ICCASM 2010), 2010.

[10]Mayuresh Sardar, "Programmable OP-AMP Configurations", International Research Journal of Engineering and Technology (IRJET)", 2016.

[11]Yohanes Oxa Wijaya, Florentinus Budi Setiawan, Siswanto, "Desain dan Implementasi Alat Pengukur Ketegangan Otot", Industrial Research Workshop and National Seminar (IRWNS), 2014..

[12]CHEN Xian-Feng, HE Ya-fei, SHEN Xin-di, Chen Qingzhang, "Development of A Pulse-Type Servo Drive System and the Appication on a 3Axises Robot", 2nd International Asia Conference on Informatics in Control, Automation and Robotics, 2010. 